\title{
5. \\ JAROSLAV ŠIDAK U GLAZBENOM \\ ŽIVOTU MEĐURATNOG ZAGREBA
}

\section{Ivana Šubic Kovačević i Damir Agičić}

UDK: 929Šidak. J.:78(051)“1927/1930“

Izvorni znanstveni članak

Sažetak: U radu se na temelju arhivske građe i analize novina Jugoslavenski muzičar/Muzičar analizira djelovanje Jaroslava Šidaka u glazbenom životu međuratnog Zagreba. Jaroslav Šidak bio je glavni urednik spomenutih novina od 1927. do 1930. godine. Pisao je i uređivao tekstove u svojim ranim dvadesetima, a ostavku na položaj urednika dao je početkom ljeta 1930. godine. Kao razlog njegova odlaska s uredničkog položaja navodi se preopterećenost obvezama. Očito se od izdavanja i vođenja usko specijaliziranog časopisa nije moglo živjeti, nego se valjalo posvetiti drugim stvarima. U brojnim tekstovima koje je Šidak pisao može se uočiti jedna njegova karakterna crta - borba za pravednost i nastojanje da se pomogne drugima u njihovu radu, dakle upravo ona karakteristika koju su mnogi povjesničari kasnije isticali o Šidaku kao sveučilišnom profesoru povijesti i glavnom uredniku Historijskog zbornika.

Ključne riječi: Jaroslav Šidak, Fran(jo) Šidak, Jugoslavenski muzičar/Muzičar, Savez muzičara u Kraljevini SHS, Zagreb, kulturni život

I.

27. ulturni život u Zagrebu nakon Prvoga svjetskog rata odvijao se na nekoliko mjesta. Najznačajnija su bila: prva glazbeno-obrazovna ustanova u Zagrebu Hrvatski glazbeni zavod (1827.) i Hrvatsko narodno kazalište (1870.) te zagrebački privatni saloni, kina, kavane, kabareti i dr. Glazbeni život u Zagrebu bio je bogat jer je u njemu živjela plejada izvrsnih glazbenika i kompozitora. ${ }^{1}$ U Zagrebu je djelovao Zagrebački kvartet (1919.), Zagrebačka filharmonija (1920.), Kazališni orkestar (1898.), Zagrebački madrigalisti (1930.), pjevačko društvo „Kolo“, „Sloboda“ i „Glazbeno društvo intelektualaca“2 te druga pjevačka

„Zagreb“, Jugoslavenski muzičar (Zagreb), god. II, br. 2, 1. 2. 1924., 3.

2 Glazbeno društtvo intelektualaca bilo je mješoviti zbor od 76 pjevača. Osnovano je 1920. godine, a bavilo se promoviranjem slavenske glazbe i slavenskih kompozitora. Arhiv Jugoslavije, Ministarstvo prosvete Kraljevine Jugoslavije, Umetničko odelenje, Muzička umetnost/Pevačka i muzička društva, fond 66 (dalje: AJ-66, Ministarstvo prosvete KJ), kut. 371, Zamolba Glazbenog društva intelektualaca Kralj. Ministarstvu prosvjete od 12. XII. 1930. 
društva. ${ }^{3}$ Zagrebačka filharmonija u to vrijeme nije imala stalne članove, glazbenike koji su svirali, zbog čega je pripremanje programa velikih kompozitora bilo teže jer se nije moglo kontinuirano raditi. ${ }^{4}$ Unatoč tome, poznati kompozitor i glazbeni kritičar Stanislav Stražnicki ${ }^{5}$ smatra kako su izvedbe Zagrebačke filharmonije bile dobre s obzirom na to da nije imala stalnog dirigenta i stalni program. ${ }^{6}$

Na zagrebačkoj su se sceni, osim klasičnih djela, prikazivala i brojna suvremena te nova operna i baletna djela. ${ }^{7}$ Zvanje glazbenika u poslijeratnom razdoblju nije bilo nimalo lako. Služba koju su osiguravali privatni poduzetnici (uglavnom ugostitelji i kinematografi) bila je sezonska i nestalna. Ugovori su se sklapali na kratka razdoblja, a plaća je bila mizerna. Stalni ugovori nisu postojali, a o stalnom zaposlenju glazbenici su mogli samo sanjati. Privatni glazbenici nailazili su na mnoge probleme: radili su bez odmora od osam do deset sati, sedam dana u tjednu, bez ijednog slobodnog dana (za glazbenike su vikendi uvijek bili „udarni“); u slučaju bolesti, bolovanje im ne bi bilo plaćeno, $s$ time da su morali sebi naći zamjenu (nasreću, liječničku su pomoć i lijekove dobivali besplatno). Godišnjeg odmora nisu ni imali. Zbog rješavanja svih tih problema javila se potreba za osnivanjem jedne organizacije - Saveza muzičara - čiji je cilj bio zaštititi ne samo privatne nego i općenito sve glazbenike. ${ }^{8}$

Savez muzičara u Kraljevini Srba, Hrvata i Slovenaca nastao je reorganizacijom Saveza glazbenika kraljevine Hrvatske i Slavonije u Zagrebu 15. rujna 1923. te pripajanjem nekoliko drugih saveza iz Hrvatske, Srbije i Slovenije.' Službeno ujedinjenje svih saveza dogodilo se na konferenciji u Beogradu, održanoj od 20. do 22. veljače $1924 .{ }^{10}$ Usporedno $s$ radom Saveza u Zagrebu nastavili su raditi Sekcija muzičara u okviru Saveza privatnih namještenika i Jugoslavensko udruženje muzičara (JUM). ${ }^{11}$ Idejni začetnik Saveza muzičara u Kraljevini SHS bio je Franjo Šidak, koji je pokretanjem lista Jugoslavenski muzičar dao ideju jedne jedinstvene organizacije koja bi okupila sve glazbenike na jednome mjestu. Njezin cilj bio je ujediniti sve glazbenike u jednu organizaciju kako bi se mogla voditi lakša i bolja evidencija o glazbenicima te kako bi im se omogućili bolji životni uvjeti i novčano pomaganje u slučaju bolesti ili nezaposlenosti. ${ }^{12}$ Franjo Šidak smatrao je da se

\footnotetext{
Sanja Majer Воветко, Glazbena kritika na hrvatskom jeziku između dvaju svjetskih ratova, Zagreb 1994., 29.

AJ-66, Ministarstvo prosvete KJ, kut. 371, Molba Ministarstvu prosvjete za podjelu subvencije od 30. XII. 1930.

Stanislav Stražnicki bio je muzički pisac i kritičar (Križevci, 1883. - Zagreb, 1945.).

6 „Muzički život u Zagrebu“, Jugoslavenski muzičar (Zagreb), god. V, br. 3, 4. 3. 1927., 5-6. O glazbenoj kritici na hrvatskom v. S. MAJer BoвETKo Glazbena kritika na hrvatskom jeziku, 9-17.

7 S. Мајев Воветко, Glazbena kritika na hrvatskom jeziku, 29.

8 O Savezu muzičara v. Ивана Весиъ і Весна Пено, Између уметности и живота. О делатности удружења музичара у Краљевини СХС/Југославији, Beograd 2017.

9 AJ-66, Ministarstvo prosvete KJ, kut. 620, Pravila društva Saveza muzičara u Kraljevini SHS od 22. II. 1924. u Beogradu.

10 „Izvještaj Zagrebačkog podsaveza“, Jugoslavenski muzičar (Zagreb), god. II, br. 4, 1. 4. 1924., 2-3.

11 Jugoslavensko udruženje muzičara nastalo je 1920. godine u Zagrebu. Svojim je programom dosta slično Savezu muzičara u Kraljevini SHS, osim što je ovo udruženje okupljalo sve glazbenike, glazbene pedagoge, kompozitore, muzikologe i dirigente, tj. sve kvalificirane glazbenike. Cilj udruženja bila je briga o kulturnom napredovanju članstva i promoviranje njihovih ostvarenja, razvoj glazbeno obrazovanih ljudi, kao i nadziranje rada glazbenih privatnih i javnih škola u kojima se podiže glazbeni pomladak. AJ-66, Ministarstvo prosvete KJ, kut. 620, Dopis Ministarstvu prosvete od 20. V. 1920. u Beogradu, 1.

12 AJ-66, Ministarstvo prosvete KJ, kut. 620, Pravila društva Saveza muzičara u Kraljevini SHS od 22. II. 1924. u Beogradu.
} 
stvaranjem takve organizacije „pokazuje duh naprednosti, koji se odrazuje u inteligenciji samih članova jednog staleža“."13

Središte Saveza muzičara Kraljevine SHS nalazilo se u Beogradu. ${ }^{14}$ Činilo ga je šest podsaveza: Beogradski, Zagrebački, Ljubljanski, Splitski, Novosadski i Sarajevski. ${ }^{15}$ Savez muzičara je kao središnji cilj svoga rada isticao podizanje materijalnog i socijalnog položaja svakoga glazbenika. ${ }^{16}$ Nadalje je smatrao kako bi se položaj glazbenika u društvu svakako trebao urediti zakonom te da bi zakon o zaštiti profesionalnih glazbenika i zakon o glazbenoj komori mogli pomoći glazbenicima kako bi ih se ozbiljnije shvatilo i kako bi se više poštovala njihova profesija. Među ostalim, smatralo se da bi glazbenici, kao i sva ostala „radna snaga“, trebali imati jedan slobodan dan u tjednu, točno određenu satnicu i dnevnicu te ustanovu orkestralnih povjerenika koji bi zastupali određeno zanimanje u „gorućim pitanjima“. Glazbenici u kazalištima uspjeli su se izboriti za slobodni ponedjeljak s obzirom na to da im je nedjelja bila radna. ${ }^{17}$

Franjo Šidak kao tajnik Zagrebačkog podsaveza bio je nazočan i na prvoj osnivačkoj sjednici u Zagrebu. ${ }^{18} \mathrm{Na}$ toj je sjednici podsjetio sve nazočne kako Savez glazbenika Kraljevine Hrvatske i Slavonije od početka do kraja rata nije pokazivao zanimanje za rješavanje ključnih problema svih glazbenika u državi. Budući da ni druga udruženja (Udruženje jugoslavenskih muzičara u Zagrebu i Sekcija glazbenika u Savezu privremenih namještenika) svojim radom nisu odgovarala interesima glazbenika, Šidak je predložio reorganizaciju Saveza glazbenika Kraljevine Hrvatske i Slavonije te stvaranje novog Saveza muzičara. Tom je prilikom naglasio kako naziv „Glazbenici Hrvatske i Slavonije“ nikako ne odgovara tadašnjem teritorijalnom ustroju države te da bi u naziv trebalo staviti odrednicu „Kraljevine SHS“, oko čega su se svi nazočni složilii. ${ }^{19}$ Franjo Šidak bio je prisutan na gotovo svim sjednicama Saveza muzičara kao tajnik udruženja. Na drugoj skupštini u Zagrebu dao je kratak pregled rada Saveza muzičara te predložio osnivanje Unije muzičara za Kraljevinu SHS koju bi činili svi glazbenici u Sloveniji, Srbiji i Hrvatskoj. Pristanak za takvu organizaciju dobili su od Slovenaca, ali ne i od Srba, koji nisu poslali niti jednog predstavnika na skupštinu. Svoj je referat Šidak završio riječima: „Živila sloga! Živio Savez muzičara! Živila Unija jugoslavenskih muzičara. ${ }^{\text {"20 }} \mathrm{Na}$ sjednici je proglašen vlasnikom Jugoslavenskog muzičara. ${ }^{21}$ Njegov sin Jaroslav u rad tijela Saveza muzičara ušao je kasnije, 1929., kao član Nadzornog odbora, zajedno s Karlom Prochaskom, Franjom Kubačekom

„Drugovi“, Jugoslavenski muzičar (Zagreb), god. I, br. 1, 15. 8. 1923., 1.

AJ-66, Ministarstvo prosvete KJ, kut. 620, Pravila društva Saveza muzičara u Kraljevini SHS.

„Izvještaj Zagrebačkog podsaveza“, Jugoslavenski muzičar (Zagreb), god. II, br. 4, 1. 4. 1924., 2-3.

16 „Socijalna zaštita muzičara u privatnim poduzećima“, Jugoslavenski muzičar (Zagreb), god. IV, br. 12, 11.12. 1926., 1.

17 „Sedmični počinak, radno vrijeme i povjerenici“, Jugoslavenski muzičar (Zagreb), god. IV, br. 12, 11. 12. 1926., 1-2.

18 „Zapisnik sastanka muzičara u Zagrebu“, Jugoslavenski muzičar (Zagreb), god. I, br. 3, 20. 10. 1923., 2.

19 Isto.

20 Isto.

21 Zaključci sjednice bili su: da se osnuju podsavezi u Splitu, Sarajevu i Novom Sadu; da se u Upravu Saveza muzičara biraju iz svakog podsaveza dvojica članova i dvojica zamjenika; da se posmrtni fond vodi u Zagrebu, kao središnji, dok bi se pripomoćni fond prema prilikama vodio u središtima pojedinih podsaveza; da se počne s radom za kongres muzičara za Kraljevinu SHS ljeti 1924. godine; da se predsjednika Simu Pavličevića pošalje u Split i Šibenik kako bi osnovao podsaveze. „Izvanredna glavna skupština“, Jugoslavenski muzičar (Zagreb), god. I, br. 3, 20. 10. 1923., $2-4$. 
i Franjom Štefanom. ${ }^{22} \mathrm{Uz}$ oca je Jaroslav Šidak radio i pomagao u uredništvu Jugoslavenskog muzičara.

Redoviti član Saveza muzičara mogao je biti svaki glazbenik instrumentalist, kompozitor, dirigent, pedagog i organist (izuzimali su se vojni muzičari, tamburaši, harmonikaši, vokalisti itd.), koji je stalno ili privremeno živio u Kraljevini SHS, bez razlike spola, vjere i mjesta stanovanja. ${ }^{23}$ Redoviti član nije smio biti mlađi od 16 godina. Svaki takav član primljen u Savez dobivao je člansku knjižicu s fotografijom koju su potpisivali predsjednik, tajnik i blagajnik. Svaka je članska iskaznica nosila broj registra pod kojim je uveden pojedini član i imala je žig podsaveza. ${ }^{24}$ Uvođenjem iskaznica mogao se pratiti broj članova, a samim time mogla se voditi evidencija o pojedinim članovima u podsavezima.

Broj je članova u Savezu iz godine u godinu rastao. Najviše je članova imao Zagrebački podsavez, gdje su 1925. godine bila 232 člana, 1926. već 270 , potom se za vrijeme diktature 1929. broj smanjio na 210, da bi ih 1935 . bilo $250 .{ }^{25}$ Pred Drugi svjetski rat broj članova u Zagrebačkom podsavezu smanjio se na 205. Najmanje članova imao je Subotički podsavez, koji je zbog malog broja glazbenika (21 - 35 članova) djelovao samo do 1929. godine. Po broju članova, iza Zagreba bio je Beogradski, pa Ljubljanski podsavez. Beogradski podsavez u razdoblju između 1925. i $1940 .{ }^{26}$ imao je između 100 i 198 članova, dok je Ljubljanski brojio od 62 do 110 članova. Od 1935. taj se broj smanjuje, a razlog je neuviđanje „ikakve koristi“" od Saveza jer nije nudio neka socijalna ili ekonomska rješenja. Iako u pojedinim izvješćima stoji da je brojčano stanje bilo preko tisuću članova, analizom podataka vidimo da njihov broj nije bio veći od 715 , premda i taj broj nije posve siguran jer ne znamo jesu li u nj ulazili svi članovi ili samo oni aktivni. ${ }^{27}$

Tablica 1. Broj članova Saveza muzičara u Kraljevini SHS/Jugoslaviji

\begin{tabular}{|l|c|c|c|c|c|c|c|}
\hline Grad & $\mathbf{1 9 2 5 .}$ & $\mathbf{1 9 2 6 .}$ & $\mathbf{1 9 2 9 .}$ & $\mathbf{1 9 3 2 .}$ & $\mathbf{1 9 3 5 .}$ & $\mathbf{1 9 3 7 .}$ & $\mathbf{1 9 4 0 .}$ \\
\hline Zagreb & 232 & 270 & 210 & 208 & 250 & 221 & 205 \\
\hline Beograd & 182 & 173 & 100 & 119 & 315 & 132 & 198 \\
\hline Ljubljana & 71 & 90 & 70 & 110 & 150 & 62 & 80 \\
\hline Subotica & 21 & 35 & 22 & - & - & - & - \\
\hline Ukupno & $\mathbf{5 0 6}$ & $\mathbf{5 6 8}$ & $\mathbf{4 0 2}$ & 437 & 715 & 415 & 483 \\
\hline
\end{tabular}

Pitanje glazbenika i salonskih orkestara bilo je jako važno, o čemu svjedoči traženje obrtnice i koncesije za svakoga glazbenika ili salonskog izvođača. Savez muzičara također se bri-

22 „Zapisnik“, Jugoslavenski muzičar (Zagreb), god. VII, br. 4, 25. 4. 1929., 7.

23 AJ-66, Ministarstvo prosvete KJ, kut. 620, Pravila društva Saveza muzičara u Kraljevini SHS od 22. II. 1924. u Beogradu.

24 Isto

25 „Zapisnik“, Jugoslavenski muzičar (Zagreb), god. VII, br. 4, 25. 4. 1929., 1.

26 "Zapisnik“, Jugoslavenski muzičar (Zagreb), god. XVI, br. 1, 5. 1. 1937., 1.

27 U vezi s brojčanim pokazateljem članova Saveza muzičara u Kraljevini SHS/Jugoslaviji treba biti jako oprezan jer u arhivskoj građi nisu pronađeni točni podaci. Brojke donosi Jugoslavenski muzičar na svakom kongresu Saveza muzičara. Broj članova u izvješćima dosta često varira zato što se nekada broje i neaktivni članovi, tj. oni koji nisu platili članarinu više od tri mjeseca. 
nuo za bolju naobrazbu glazbenika i njihovo usavršavanje. Naime, članovi Saveza muzičara u Kraljevini SHS smatrali su kako svaki vođa salonskog orkestra treba položiti ispit kojim bi dobio koncesiju za voditelja orkestra. ${ }^{28}$ Zagrebački podsavez, uz dopuštenje Umjetničkog odjeljenja Ministarstva kulture, smatrao je kako vođa salonskog orkestra treba proći jednogodišnji teorijski tečaj na kojem bi naučio teorijski dio glazbenih oblika, harmoniju i povijest glazbe. Polaganjem stručnog ispita i dobivanjem obrtnice amaterski glazbenici bili bi priznati kao „profesionalni glazbenici“ te su s takvom obrtnicom mogli svirati svugdje. Pravo na koncesiju dobivalo se pri Umjetničkom odjeljenju Ministarstva prosvjete u Beogradu. Pravila o izdavanju koncesije i umjetničke obrtnice donesena su na sjednici 22. studenoga 1926. u Beogradu, na kojoj su sudjelovali predsjednik Umjetničkog odjeljenja Milan Dimović, članovi Izvršnog odbora Saveza muzičara u Kraljevini SHS Petar Krstić, Ivan Brezovšek i Karlo/Karelj Thot, predstavnik Ljubljanskog podsaveza Matija Bravničar te predstavnici Zagrebačkog podsaveza Stanislav Stražnicki i Srečko Kumar. ${ }^{29}$ U vezi s pitanjima na ispitu za koncesiju za vođe salonskih orkestara došlo je do prigovora oko cijelog koncepta ispita i njegova polaganja. ${ }^{30}$ Neki su smatrali da su ispiti prelagani te da bi trebali obuhvaćati teorijski i glazbeni dio. ${ }^{31}$

U razdoblju od 1927. do 1930. ustalili su se ispiti za salonske vođe koji su se sastojali od dvaju dijelova - prvi je dio bio pisani, a drugi usmeni. Naredbu o tome kako ispit treba izgledati i što se sve mora priložiti izdalo je Ministarstvo unutarnjih poslova 18. ožujka 1930. godine. ${ }^{32}$ Nakon višegodišnjeg iskustva u radu na izdavanju dozvola vođama salonskih orkestara, pojavila se 1933. potreba za izmjenom i dopunom važećeg pravilnika. $\mathrm{Na}$ kongresu 1933. raspravljalo se o dvama, kasnije trima pravilnicima. ${ }^{33}$

Prvi pravilnik trebao je biti namijenjen vođama salonskih orkestara, drugi „učiteljima muzike" i treći vođama puhačkih orkestara. Prijedlozi oko koncesioniranja poslani su na odobrenje nadležnim ministarstvima - Ministarstvu prosvjete, Ministarstvu socijalne politike i Ministarstvu unutrašnjih poslova. Nefunkcioniranje države i njenih upravnih tijela vidljivo je i u prihvaćanju Pravilnika o koncesioniranju jer se ministarstva nisu mogla složiti oko valjanosti tih pravilnika. ${ }^{34}$ Svako ministarstvo imalo je svoje primjedbe. Na kraju je 1938. Ministarstvo prosvjete, koje je prvotno odobrilo Pravilnik o izdavanju koncesija vođama salonskih orkestara, odlučilo da pravilnik nije dovoljno pravno specificiran i da Savez muzičara nema pravo imati „monopol“ na izdavanje takvih koncesija. Od pravila za koncesije nije se odustalo niti 1940./1941., kada je Zagrebački podsavez Hrvatskog saveza kvalificiranih muzičara Vladi Banovine Hrvatske podnio zahtjev za prihvaćanjem pravila. ${ }^{35}$

$\overline{28}$ „Teoretsko-muzička izobrazba vodja salonskih orkestara“, Jugoslavenski muzičar (Zagreb), god. IV, br. $11,4.11$. 1926., 6.

29 „Konferencija o pitanju koncesija za vodje salonskih orkestara“, Jugoslavenski muzičar (Zagreb), god. IV, br. $12,11$. 12. 1926., 2-3.

30 „Zapisnik“, Jugoslavenski muzičar (Zagreb), god. VII., br. 4, 25. 4. 1927., 8.

31 Isto.

32 „Ispiti za vođe salonskih orkestara“, Muzičar (Zagreb), god. IX, br. 9, 20. 9. 1931., 5.

33 „Zapisnik“, Muzičar (Zagreb), god. XI, br. 14, 20. 7. 1933., 1-2.

34 AJ-66, Ministarstvo prosvete KJ, kut. 371, Ministarstvu prosvete u Beogradu, Zapisnik od 18. VII. 1934. u Beogradu.

35 „Zapisnik“, Muzičar (Zagreb), god. XVIII, br. 6, 5. 6. 1940., 2. 
Jezgra pokreta Saveza muzičara u Kraljevini SHS u Zagrebu bilo je Hrvatsko narodno kazalište, čiji su svi članovi bili uključeni u Zagrebački podsavez. ${ }^{36}$ Upravitelj (pročelnik) kazališnog orkestra u Zagrebu tada je bio Umberto Fabbri ${ }^{37}$, koji je kasnije postao predsjednik Saveza muzičara. ${ }^{38}$ On se zalagao da se svi glazbenici iz kazališnog orkestra učlane u Savez muzičara u Kraljevini SHS. Cilj je bio ujediniti sve glazbenike u jednu organizaciju, kako bi se mogla voditi lakša i bolja evidencija o glazbenicima. Budući da su i glazbenici u Hrvatskom narodnom kazalištu u Zagrebu bili u socijalno nezaštićenom položaju, članstvo u Savezu muzičara Kraljevine SHS osiguravalo im je socijalnu i pravnu zaštitu.

Savez je djelovao na učvršćivanju podsaveza u Beogradu, Zagrebu, Ljubljani, Splitu, Novom Sadu i Sarajevu. Radio je na: 1. osnivanju podružnica te imenovanju povjerenikâ u manjim mjestima; 2 . osnivanju glazbene komore te potpornog i posmrtnog fonda; 3 . tome da Savez muzičara bude priznat kao kompetentno tijelo u svim profesionalnim pitanjima vezanima za profesiju glazbenika; 4. uspostavljanju kontakata sa sličnim udruženjima u inozemstvu. Jedan od glavnih ciljeva bio je uspostaviti normalan odnos između civilnih glazbenika i vojne glazbe jer je potonja svojom niskom tarifom rada rušila cijenu profesionalnim glazbenicima. Nastojalo se objavljivati djela domaćih kompozitora te se radilo na uređivanju glavnoga glasila Saveza muzičara Jugoslavenskog muzičara.

Jaroslav Šidak (1903. - 1986.) ulazi među najznačajnije i najpoznatije hrvatske povjesničare u dvadesetom stoljeću. Bio je gimnazijski i potom sveučilišni profesor, jedan od osnivača Povijesnog društva Hrvatske (1947.), dugogodišnji glavni urednik najstarijeg i dugo vremena glavnoga časopisa hrvatske historiografije Historijski zbornik (1948. - 1985.). No, manje je poznato da se tijekom i neposredno nakon studija povijesti, koji je završio na Filozofskom fakultetu u Zagrebu 1926. godine, bavio glazbom svirajući klavir, ali i pišući tekstove o glazbenim temama, napose o položaju i strukovnom organiziranju glazbenika, te uređujući časopis posvećen glazbenicima i glazbenom životu u Zagrebu, Hrvatskoj i Jugoslaviji. Riječ je o Jugoslavenskom muzičaru, odnosno Muzičaru, časopisu koji je 1923. godine pokrenuo njegov otac Fran(jo) Šidak, vlasnik prodavaonice glazbala i literature o glazbi u Zagrebu, kamo se doselio u predvečerje Prvoga svjetskog rata. Šidakova se prodavaonica,

36 „Izvještaj Zagrebačkog podsaveza“, Jugoslavenski muzičar (Zagreb), god. II, br. 4, 1. 4. 1924., 2-3.

37 Umberto Fabbri bio je predsjednik Zagrebačkog podsaveza od ožujka 1929. do travnja 1941. Dolazi iz jedne talijanske umjetničke obitelji, gdje mu je otac bio poznati violončelist. Kao sjajni violončelist imao je nastupe po Francuskoj, Švicarskoj i Italiji, a profesorsku karijeru započeo je kao profesor violončela na Konzervatoriju u Hrvatskom glazbenom zavodu, kasnije Muzičke akademije u Zagrebu. Kasnije je radio u Zagrebačkoj filharmoniji, Zagrebačkom kvartetu i drugim ansamblima. Za njegova mandata Savez muzičara Jugoslavije prošao je različite promjene - među njima svakako treba naglasiti državnu podjelu na banovine, a samim time i podjelu na podsaveze, kao i mijenjanje naziva Zagrebačkog podsaveza u Hrvatski savez kvalificiranih muzičara. U razdoblju njegova predsjednikovanja napravljeni su novi pravilnici za posmrtni fond i novi nacrt kolektivnog ugovora. Svakako je najveći problem u tom razdoblju bila filmska glazba i kinematografi koji su glazbenike u toj branši doveli do ruba egzistencije, točnije, zanimanje glazbenika u kinima prestalo je postojati. Leksikon Jugoslavenske muzike (ur. Krešimir Kovačević), knj. I., Zagreb 1984., 234.

38 „Orkestar Narodnog kazališta u Zagrebu“, Jugoslavenski muzičar (Zagreb), god. II, br. 12 (16), 1. 12. $1924 ., 1$. 
„Muzikalije Franje Šidaka“, nalazila u Ilici 40/Dežmanovoj 1, ondje gdje je danas Dežmanov prolaz. Zasigurno je obiteljsko okruženje utjecalo na to da mladi Jaroslav zasvira te tako zarađuje i svoje prve honorare. Uz to je pomagao ocu u prodavaonici, ali i u vođenju i uređivanju strukovnoga časopisa. Jaroslav Šidak uređivao je Jugoslavenskog muzičara/Muzičara nekoliko godina - od samoga je početka pomagao u uređivanju, a formalno je urednik bio između 1927. i 1930. godine. Pisao je i uređivao tekstove u svojim ranim dvadesetima, a ostavku na položaj urednika dao je početkom ljeta 1930. godine, kada je navršio 27 godina. Kao razlog njegova odlaska s uredničkog položaja navodi se preopterećenost obvezama. Očito se od izdavanja i vođenja usko specijaliziranog časopisa nije moglo živjeti, nego se valjalo posvetiti drugim stvarima. Valja znati i da se Šidak dvije godine ranije oženio. Posao gimnazijskog profesora dobio je 1934., kada je počeo raditi u Senju. Njegova je glazbena karijera time završila, a započela je nastavnička i znanstvena. Intenzivno se posvetio radu na disertaciji pa je nekoliko godina potom i doktorirao.

Jaroslav Šidak bio je, dakle, glavni urednik Muzičara od 1927. do 1930. Od 1927. do 1941. izdavač i vlasnik toga glasila bio je Savez muzičara, a odgovorni urednik Milivoj Kern (1929. - 1931.). ${ }^{39}$ Šidak je list vodio pametno i savjesno sve do kongresa u Ljubljani 28. i 29. lipnja 1930., kada je dao ostavku na mjesto urednika. Prema zaključku kongresa, organiziran je redakcijski odbor pa je tako redakciju Muzičara privremeno preuzeo tadašnji tajnik Saveza Milivoj Kern. ${ }^{40}$ Cilj glasila bio je zaštititi interese profesionalnih glazbenika u međuratnoj Jugoslaviji. Iz tog razloga velik broj članaka bavi se njihovim socijalnim problemima: zapošljavanjem, socijalnim osiguranjem, statusom, kao i organizacijskim problemima Saveza muzičara u Kraljevini SHS. Jugoslavenski muzičar u člancima se bavio i drugim problemima koji su glazbenicima oduzimali posao, kao što su zvučni film, radio, gramofon, vojna glazba, strani glazbenici i dr.

Jaroslav Šidak svoje je radove u Jugoslavenskom muzičaru/Muzičaru potpisivao sa šk (tako se i kasnije potpisivao pod svoje opsegom manje tekstove u časopisu Historijski zbornik). Radove je objavljivao i prije nego što je postao glavni urednik novina. U razdoblju 1927. 1930. napisao je u Jugoslavenskom muzičaru/Muzičaru više od šezdeset tekstova. Njegovi su članci duboko ulazili u problematiku same struke. U Savezu muzičara bio je član Nadzornog odbora te je shvaćao glavne probleme glazbenika. Koliko je bio uronjen u problematiku rada Saveza muzičara najbolje govore njegovi članci u Muzičaru o ozbiljnim temama, primjerice, o nepostojanju stalnih ugovora, stalnoj fiksnoj tarifi, glazbenicima koji nisu imali obrtnicu ni pravo na koncesiju, niti zdravstveno osiguranje, mirovinu i slobodne dane, a probleme su im radili strani glazbenici i vojna glazba, potom o nelojalnom odnosu unutar struke i, na kraju, o zvučnom filmu i gramofonu.

Rad u ovome časopisu i općenito u strukovnom glazbeničkom društvu Šidaku je zasigurno bila dobra škola pa se dvadesetak godina kasnije, već kao sveučilišni profesor povijesti, mogao upustiti u osnivanje Povijesnog društva Hrvatske i vođenje/uređivanje $\mathrm{Hi}$ storijskog zbornika. Već je radeći u Savezu muzičara razumio koliko značajna može biti

39 Milivoj Kern Mačković bio je novinar i humorist (Samobor, 1890. - Zagreb, 1970.).
40 „Sa kongresa u Ljubljani“, Muzičar (Zagreb), god. VIII, br. 10, 25. 12. 1930., 1. 
strukovna udruga, a napose njezino glasilo. Osjećao je mnoge probleme koji su karakteristični za većinu udruga, i onda kao i danas - da velik broj članova nije spreman raditi, da su brojni članovi u udruzi samo radi određenih povlastica, a nisu čak u stanju ni redovito plaćati članarinu. Nije se libio kritizirati rad Saveza muzičara, pa ni njegovo vodstvo:

Organizacija nije nikakvo bezlično tijelo, ona živi prije svega u svojim funkcionerima i u masi članova ni ne postoji drugo mišljenje, nego da vodeći funkcioneri stvarno tvore organizaciju. Svijest, da organizacija ima da predstavlja zajednicu izvjesnih skupnih interesa i da svaki njezin član treba da u nju unosi što više neposredne pažnje, strana je pretežno većini članova i sa tom činjenicom treba računati, ma koliko ona bila teška... Onaj koji ne osjeća u sebi volje za taj rad, neka ne prihvaća funkcije, ali koji to čini, treba da znade, da ne pristupa jednoj djetinjskoj igri, nego radu na promicanju dubokih životnih interesa. ${ }^{41}$

Često je naglašavao kako je Savez muzičara staleška organizacija te da mu se moraju pridružiti i profesionalni glazbenici. ${ }^{42}$ Sudjelovao je na gotovo svakom kongresu i sjednici Saveza muzičara, a o zaključcima informirao je svoje čitatelje. Obavještavao ih je i o radu Zagrebačkog podsaveza. ${ }^{43}$ Smatrao je da Savez muzičara raspolaže „svim značajkama jedne izrazito sindikalne strukovne organizacije" i to je često naglašavao. ${ }^{44}$ Politika Saveza muzičara bila je, naime, omogućiti glazbenicima bolji život:

Svrha organizacije nije u tome, da svoga člana potpomogne u bolesti i nezaposlenosti, nego da izmijeni životne i radne uslove čitave profesije, da je materijalno, socijalno i kulturno diže sve više, oslobađajući je postepeno, smišljenom borbom, pritiskom onih čimbenika, koji joj danas onemogućavaju čovjeka dostojan život. ${ }^{45}$

Mnogi su problemi morili glazbenike međuratnog razdoblja, a jedan je od njih svakako bila vojna glazba, koja je svojom cijenom rušila cijenu profesionalnim glazbenicima. Na to su ukazivali članovi Saveza muzičara već na svojoj prvoj konferenciji, kao i na ostalima, nastojeći da se problem riješi. To ipak nije bilo moguće u prvim godinama postojanja Saveza jer su tada druga pitanja bila prioritetna, primjerice, ona vezana za administraciju, članarine ili fondove. No, ranije spomenuti problem mogao se pokušati riješiti kada je izrađena detaljna evidencija glazbenika, što je Savez muzičara riješio upitnicima. ${ }^{46}$ Krajem 1926. krenulo se s rješavanjem problema vojne glazbe. Odlučeno je da će se rješavati na višoj instanciji jer primjedbe i žalbe vojnim kapelnicima očito nisu riješile stvar. Naime, velik je broj civilnih glazbenika zbog nedostatka angažmana oblačio vojne uniforme i privremeno svirao u vojnoj glazbi. Potonja je najviše teškoća zadavala u većim gradovima - Zagrebu, Beogradu, Ljubljani, Subotici i dr. - jer je u njima kulturni i društveni život cvjetao, a povećanjem vremena za razonodu rasla je potražnja za civilnim glazbenicima. Jaroslav Šidak o vojnoj je glazbi pisao sa stanovitim razumijevanjem položaja vojnih glazbenika:

\footnotetext{
41 „Povodom drugog redovnog kongresa Savezne Uprave“, Muzičar (Zagreb), god. VI, br. 4, 18. 4. 1928., 1-2.

42 „Neorganizovanim muzičarima“, Jugoslavenski muzičar (Zagreb), god. V, br. 1, 8. 1. 1927., 1.

43 „Poslije izvanrednog kongresa“, Jugoslavenski muzičar (Zagreb), god. V, br. 1, 8. 1. 1927., 3.

44 „Povodom drugog redovnog kongresa Savezne Uprave III“, Muzičar (Zagreb), god. VI, br. 6, 16. 6. $1928 ., 1$.

45 „Fondovi i posredovanje rada u sindikalnoj borbi“, Muzičar (Zagreb), god. VI, br. 8, 28. 8. 1928., 1-2.

46

„Izrađujte upitne arke“, Jugoslavenski muzičar (Zagreb), god. IV, br. 3, 1. 3. 1926., 1.
} 
(...) na njih ne treba gledati kao na konkurenciju jer oni ispunjavaju svoje dužnosti za koje ih plaća država, sviranjem kao i civilni glazbenici. To što je njihova cijena manja od privatnog glazbenika nije kriv vojni glazbenik nego njegov kapelnik koji određuje honorare vojne glazbe. ${ }^{47}$

Drugi je važan problem u međuraću bio odnos između glazbenika i kapelnika, odnosno salonskih vođa. U tom je sporu Šidak bio oštar prema potonjima, smatrajući da su se vođe često

ponašali kao vlasnici orkestara pa su, osim što su određivali dnevnice, često ugnjetavali i mijenjali svoje članove prema svom vlastitom nahođenju. Pri tome vlasnici restorana, kluba ili bara nisu imali nikakav kontakt s glazbenicima, a kamoli utjecaj na ponašanje kapelnika prema svojim kolegama. ${ }^{48}$

Šidak je smatrao da je „takav odnos između kolega nelojalan i nedopustiv te bi se svakako morao mijenjati“ ${ }^{49}$ Naravno, nisu ni vlasnici lokala, kavana i restorana bili oličenje korektnosti i poštenja. Često su glazbu u lokalu puštali na radiju a da salonskim glazbenicima i kapelnicima ništa nisu platili. ${ }^{50}$ Nelojalnu su konkurenciju predstavljali i agenti koji se često nisu držali sklopljenog ugovora. U jednom je članku Šidak komentirao rad agenata kao poslovanje koje je lihvarsko i koje bi se odmah moralo zaustaviti jer Savez muzičara i savezna kancelarija za zaposlenja, koja je ovlaštena poslove davati glazbenicima, postoje upravo iz takvih razloga. ${ }^{51}$ Tvrdio je da „agenti kao takvi postoje i njima se ne može zabraniti rad, osim ako posluju nepošteno i ako su za svoju prevaru prijavljeni policiji“ "52 Glazbenici su se, doduše, javljali agentima jer su oni bili izravni posrednici i mogućnost zarade glazbenika bila je veća i brža. Traženje posla preko Saveza muzičara bilo je duže i nije postojao osjećaj sigurnosti isplate kao što je to bilo kod agenata. Provizija agenta pri sklapanju posla bila je 5 - 10\% plaće za cijelo vrijeme angažmana. Šidak je upozoravao glazbenike da su oni ti koji kroje svoju sudbinu i da, ako posao traže uz pomoć agenata, zapravo zanemaruju Savez muzičara, koji postoji upravo radi toga - da uvede reda u zapošljavanje glazbenika i smanji njihovu nezaposlenost.

Položaj privatnih glazbenika u Kraljevini Srba, Hrvata i Slovenaca nije bio nimalo lak. Često nisu imali stalnog angažmana, niti sigurnost redovitih primanja. Nisu imali pravo na mirovinu; osobito su loše prolazili u slučaju bolesti jer tada nisu dobivali plaću, a morali su pronaći zamjenu i sami je financirati. S druge strane, niti u slučaju trajnijeg angažmana nije im bilo lako:

U vrijeme sezone on nema odmora, nema pravo u kinu da se odmori kad on to želi, nego kao stroj radi po cijele dane. Privatni glazbenik ne poznaje nedjeljni odmor, ili godišnji od-

\footnotetext{
"Jedno aktualno pitanje“, Muzičar (Zagreb), god. VII, br. 10, 20. 10. 1929., 2-3.

48 „O potkapanju egzistencije, obaranju plaća i međusobnim odnosima kapelnika i muzičara“, Muzičar (Zagreb), god. VI, br. 12, 18. 12. 1928., 1-2.

49 Isto.

50 „Besplatne radio-izvedbe salonskih orkestara“, Muzičar (Zagreb), god. VI, br. 10, 16. 10. 1928., 1-2.

51 „Privatni agenti rade!“, Muzičar (Zagreb), god. VII, br. 1, 18. 1. 1929., 2-3.

52 Isto.
} 
mor, ne poznaje osmosatno radno vrijeme. On često radi devet do deset sati dnevno bez odmora. ${ }^{53}$

Ipak, mnogo je veći problem i najveći „neprijatelj“ glazbenicima u Kraljevini SHS bila „mehanička glazba“ te pojava zvučnog filma. Zvučni film nastao je u Sjedinjenim Američkim Državama u drugoj polovini dvadesetih i isprva nije bio ništa isplativiji od nijemog. Za prikazivanje zvučnog filma bila je potrebna posebna aparatura koju kinematografi u Jugoslaviji nisu odmah imali. Pojavom zvučnog filma i „mehaničke glazbe“, zapravo gramofona, nastalo je nekoliko teškoća: raspuštaju se glazbeni orkestri, prestaju se angažirati solo-glazbenici, ugrožavaju se tarife, a upotreba „mehaničke glazbe“ ne naplaćuje se upravama kina.

Savez muzičara smatrao je da bi se „mehanička glazba“ svakako trebala naplaćivati ili makar uvesti neka taksa, čime bi se nadoknadio novac otpuštenim glazbenicima. ${ }^{54} \mathrm{~S}$ druge strane, zvučni film vrlo se brzo širio, a nijemi istiskivao te uskoro i posve nestao, zbog čega su najviše patili glazbenici koji su ostajali bez posla - više nije bilo potrebe za njihovom svirkom u kinima.

Taj problem nije mučio samo domaće glazbenike nego i strane. U Francuskoj potpisan je manifest protiv širenja „mehaničke glazbe“, dok je u Engleskoj oformljeno udruženje koje se zalagalo za kontrolu nad „mehaničkom muzikom“.55 U New Yorku je već druge godine od pojave zvučnog filma čak dvije tisuće glazbenika izgubilo posao. ${ }^{56} \mathrm{Zbog}$ velikih nameta koji su u Kraljevini SHS propisani vlasnicima kina, oni su zaprijetili štrajkom i otpuštanjem glazbenika. U Savezu muzičara objavili su na to rezoluciju u kojoj se mole vlasnici kina neka povuku svoju odluku jer ugrožavaju tisuće obitelji te su zatražili od Ministarstva financija neka se riješi pitanje kina ili će glazbene obitelji završiti na „cesti“:

Protestnim štrajkom vlasnika bioskopa u Kralj. SHS i time izazvanim otkazom namještenja, vrlo veliki broj namještenika i njihovih porodica stavljen je u položaj, koji teško ugrožava njihov opstanak. Molimo stoga Gospodina Ministra Socijalne Politike, da svojim ugledom skloni vlasnike bioskopa da povuku odluku o štrajku i otkazu, i da se zauzme za hiljade porodica na taj način, što će posredovati kod Gosp. Ministra Financija, da izadje u susret opravdanim zahtjevima vlasnika bioskopa. ${ }^{57}$

U novinama bili su česti i članci u kojima se glazbenici pozivaju na solidarnost, „da štite jedni druge i da se zalažu jedni za druge, a ne obratno “58 U brojnim tekstovima koje je o ovoj i sličnim temama pisao Šidak može se uočiti jedna njegova karakterna crta - borba za pravednost i nastojanje da se pomogne drugima u njihovu radu, dakle upravo ona karakteristika koju su mnogi povjesničari kasnije isticali o Šidaku kao uredniku Historijskog zbornika. Posebnu je pozornost pokazivao prema socijalnom statusu glazbenika, koji često nije bio osobito dobar, te sindikalnim akcijama, poput one da se pomaže članove u bolesti

53 „Obavezno penzijsko osiguranje privatnih muzičara“, Muzičar (Zagreb), god. VII, br. 3, 15. 3. 1929., 3.

54 „Mehanička muzika i orkestralni muzičari“, Jugoslavenski muzičar (Zagreb), god. V, br. 2, 15. 2. 1927., 3-4.

55 „Organizacioni pregled - Mehanička muzika i muzičari“, Muzičar (Zagreb), god. VII, br. 9, 18. 9. 1929., 1.

56 Isto.

57 „Povodom odluke kino vlasnika“, Muzičar (Zagreb), god. VI, br. 1, 16. 1. 1928., 2-3.

58 „Neophodno je potrebno da se upoznamo“, Muzičar (Zagreb), god. VI, br. 3, 15. 3. 1928., 1. Ovaj je broj tematski te donosi sve o bugarskim muzičarima i njihovoj glazbi. 
i nezaposlenosti, ili rada na stvaranju mirovinskoga fonda. Napose se angažirao u borbi protiv uvođenja zvučnoga filma jer su glazbenici bili sve manje potrebni kao zvučna pratnja filmskoj projekciji. Mnogo je tinte potrošio za napise u kojima je isticao tu pogubnost novih tendencija u filmskom svijetu. Isprva je smatrao da zagrebačkim i jugoslavenskim glazbenicima zvučni film „ne može zasada (...) nanijeti nikakve neposredne štete. [jer] nijedan od naših vlasnika kinematografa ne raspolaže onim sredstvima, koje uvođenje tonfilma zahti-

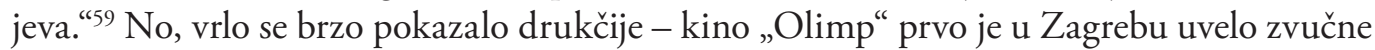
filmove, već potkraj 1929. godine, a „zainteresiranost publike je bila više nego dovoljna, pa su već neka druga kina i hale Music Hall i Metropol kino počeli s najavom ton filma“. Nije prošlo niti nekoliko tjedana i Šidak se već žalio o „velikim otpuštanjima zagrebačkih glazbenika" iz kina i isticao kako je problem dosegnuo kulminaciju.

$S$ druge strane, ni u kavanama i restoranima nije više bilo posla kao nekada jer su se zbog visokih poreza na orkestre, odnosno na honorare glazbenicima, vlasnici takvih objekata sve češće odlučivali za gramofone i puštanje glazbe s pomoću tih tehničkih pomagala. Gramofon se sve više koristio i u kultnoj kavani „Medulić, gdje su nekoć gostovali svjetski poznati orkestri. ${ }^{60}$ Inače, kafandžije i restaurateri glazbenike su često potplaćivali i podcjenjivali, nazivajući ih posprdno „muzikantima“ koji skupljaju novac na tanjuru. Nije, dakle, čudno da je profesor povijesti poželio pobjeći iz takva svijeta.

Pišući o teškom položaju naših glazbenika zbog djelovanja stranih glazbenika i uvođenja gramofona u kavanama i restoranima, Šidak u jednom svome članku nudi prijedloge kako riješiti te probleme:

1. valja uložiti sve sile u to, da se dolaženje muzičara sa strane u našu zemlju ograniči na najnužniji minimum; 2 . valja uplivisati na gradske uprave, da snize takse za namještenje orkestra; 3 . valja poraditi na tome, da se odredi razmjerno visoko porez na mehaničku reprodukciju muzike po javnim lokalima. ${ }^{61}$

Novi se problem pojavio u tridesetima - hiperprodukcija glazbenika. U jednom članku Šidak objašnjava kako su u nas glazbene škole i Akademija proizvele velik broj glazbenih intelektualaca koji, nažalost, nemaju posla jer ih se nema gdje zaposliti. ${ }^{62}$ Njihovo znanje primjenjivo je jedino u odgojnim institucijama, a one su krcate profesorima pa akademski glazbenici time ostaju bez zaposlenja. Paradoks je u tome što nema glazbenikâ koji bi svirali u restoranima, kavanama i lokalima jer su sve to vrhunski glazbenici koji su prekvalificirani. Nakon faze u kojoj uopće nismo imali školovanih glazbenika, barem ne u Zagrebu jer Muzičke akademije ondje još nije bilo, dogodilo se da ih je sada previše te da za njih nema posla.

Rezultat je ovih razvojnih okolnosti taj, da sve jače počinjemo da trpimo od nadprodukcije tzv. muzičkih intelektualaca, vodećih slojeva muzičarskog staleža; da našu potrebu za dobrim orkestralnim muzičarima moramo da pokrivamo importom izvana; da naš domaći

\footnotetext{
„Prijeti li nam opasnost od ton filma?“, Muzičar (Zagreb), god. VII, br. 10, 20. 10. 1929., 1-2.

"Snizite takse za namještenja orkestara“, Muzičar (Zagreb), god. VIII, br. 1, 20. 1. 1930., 3.

„Na ulici“, Muzičar (Zagreb), god. VIII, br. 2, 18. 2. 1930., 2.

62 „Problem naših konservatorista“, Muzičar (Zagreb), god. VIII, br. 6, 22. 6. 1930., 1.
} 
element, ukoliko se posvećuje muzici, stiče svoju muzičku izobrazbu u vojnim školama i muzikama. ${ }^{63}$

Šidak naglašava da školovani glazbenici ne mogu svirati po barovima i restoranima jer se od njih tražilo da sviraju napamet pjesme i strane kompozicije za koje nikad nisu čuli. Njegovo mišljenje o stranim glazbenicima bilo je pozitivno. Smatrao je da su oni prijeko potrebni Zagrebu s obzirom na to da su gradu nedostajali glazbenici. Napose, i na zagrebačkoj Muzičkoj akademiji velik je broj profesora bio stranog podrijetla, što nije loše, ističe Šidak. Upravo je zahvaljujući njima Hrvatska dobila nove mlade nade glazbenog života. O povećanju broja profesionalnih glazbenika Šidak piše:

Stalež profesionalnih muzičara, koji živi samo od muzike, nastaje i razvija se u gradovima, i što je urbanizacija neke zemlje dalje pokročila, t.j. što ona više gubi obilježje jedne agrarne zemlje, utoliko taj razvoj nailazi na povoljnije uslove... Naša je zadaća, da razvitak domaćeg muzičarskog staleža po mogućnosti olakšamo i pospješimo, a naša strukovna organizacija, koja je osnovana u tu svrhu, da uslove muzičarskog rada poboljša i usavrši, predstavlja onu ustanovu koja je u prvom redu zvana, da u tom redu predvodi. ${ }^{64}$

Šidak nije imao ništa protiv „uvoza“ stranih glazbenika, ali je smatrao da se „proizvodnja“ domaćih glazbenika treba planirati te da ona mora biti kvalitativno i kvantitativno zadovoljena. Ističe da se konkurencija među glazbenim staležom svakako treba ukloniti jer na svađi glazbenika profitiraju poslodavci, koji onda diktiraju poslovanje i cijenu rada. ${ }^{65}$ Također, kritizira rad Internacionalne unije, koja traži zaposlenja stranim glazbenicima u Kraljevini Jugoslaviji a da ne kontaktira sa Savezom muzičara i obavijesti ga o oglasima koje daje u svome glasilu. Šidaku je očito smetalo nelojalno ponašanje kolega i nepoštovanje pravila u kojima piše da se najprije treba kontaktirati sa savezima pojedine zemlje. U radničkom zakonodavstvu Kraljevine Jugoslavije stoji da se svi poslovi unutar neke države najprije moraju ponuditi glazbenicima te zemlje, a tek onda, u nedostatku glazbenika, mogu se nuditi strancima.

Još se jedna Šidakova karakteristika može iščitati iz njegovih tekstova o glazbenicima i problemima međuratnoga glazbenog života u Zagrebu i Jugoslaviji - odnos prema naciji i nacionalnom pitanju, kao i čvrsta sklonost slavenstvu. Češkoga podrijetla, u nacionalno heterogenoj zajednici zagrebačkih glazbenika, od kojih su mnogi bili i stranci, Jaroslav Šidak isticao je da valja „obratiti naročitu pažnju muzici slavenskih naroda“, stoga je planirao raditi na promoviranju slavenske glazbene kulture u časopisima te međusobnom informiranju i upoznavanju o tome što rade pojedini slavenski narodi na polju glazbe. Tvrdio je da

Savez [muzičara] ima zadaću nacionalnog karaktera, činjenica je kako veliki dio njegovog članstva tvore stranci, zato svako smijanje ili izrugivanje ili bilo koje vrijeđanje određene nacije treba svakako iskorijeniti iz Saveznih redova. ${ }^{66}$

\footnotetext{
63 Isto.

64 „Pitanje stranih muzičara u našoj zemlji“, Muzičar (Zagreb), god. VII, br. 2, 15. 2. 1929., 1-2.

65 Isto.

66 „Novogodišnje razmatranje“, Muzičar (Zagreb), god. VI, br. 1, 16. 1. 1928., 1-2.
} 
Neki su se članci u Muzičaru objavljivali ćiriličnim pismom, što je također bilo u duhu slavenske uzajamnosti. Šidak je smatrao da nacionalizam u glazbi nikako nije istovjetan onome u politici jer je njegova težnja usmjerena prema obogaćivanju muzičkog blaga, koje nije svojina samo jednog naroda. ${ }^{67}$ Upravo se pod njegovim utjecajem iz naslova lista odbacio pridjev jugoslavenski. Može se činiti neobičnim da se taj pridjev u naslovu lista koristio prije nego što je država dobila ime Jugoslavija, a u doba kada se država tako prozvala glazbeni se časopis zvao samo Muzičar. Šidak je objašnjavao da se time želi pokazati kako list nema nikakvu nacionalističku ili „političku boju“, nego da se želi skrbiti o svim glazbenicima na području cijele države.

Jaroslav Šidak vodio je u Muzičaru i stalnu rubriku „Muzičke bilješke“ u kojoj je čitatelje upoznavao s inozemnom i domaćom glazbom. Pisao je o koncertima Zagrebačkog kvarteta i Zagrebačke filharmonije, upoznavao čitatelje sa stranim kompozitorima i novim skladbama. Njegovo znanje o glazbi i glazbenoj literaturi jednostavno zapanjuje. Davao je iscrpne obavijesti o zbivanjima u poljskoj, bugarskoj i češkoj glazbi. Pisao je o novitetima u glazbenom svijetu, primjerice, o uvođenju orgulja kao glazbene filmske pozadine u kinu ili o glazbenim festivalima u New Yorku, Berlinu, Londonu itd. Pokrenuo je i rubriku „Muzički pregled“ (1928.), želeći potaknuti svoje kolege u ostalim podsavezima da se pokrenu i počnu raditi više za udruženje i njegovo glasilo Muzičar: ${ }^{68}$

(...) ova rubrika moći će zaživjeti samo onda ako se članci pojedinim stranim kolegama budu plaćali, ali novaca nažalost za to nema jer se list najviše financira od oglasa firma koje svoje oglasno mjesto ne plaćaju. ${ }^{69}$

Svoj rad i zalaganje u Muzičaru i Savezu muzičara Jaroslav Šidak shvaćao je jako ozbiljno pa mu nikako nije bilo jasno neodgovorno ponašanje kolega. Njegovo razočaranje radom Saveza i lista vidljivo je u nekim člancima. Nikako ne može prihvatiti činjenicu da ostali podsavezi, Beogradski i Ljubljanski, ne pridonose radu i razvitku lista i Saveza muzičara. Uređivanje strukovnoga glasila prepušteno je isključivo njemu i on se zaista u tom poslu trudi, ali boli ga nezainteresiranost članstva:

Ukratko, glasilo boluje od iste bolesti, kao i njegov vlasnik, naša strukovna organizacija. Dezinteresman članstva i nedostatak iskrenih, poduzetnih radnika u organizaciji prouzrokovali su teško shvatljivu pojavu, da glasilo živi svojim vlastitim životom, namećući se članstvu, koje u golemoj većini ne pokazuje nikakve interese za pitanja i zadatke, koji prelazi okvir svakodnevnih briga, i nagoneći uprave podsaveza, da ne prekinu svaku vezu sa svojim glasilom, osim plaćanja pretplate. Jer svako je glasilo barem jednim svojim dijelom vjeran odraz organizacije i staleža, kome je namijenjen. ${ }^{70}$

Vidno razočaran radom svojih kolega i Zagrebačkog podsaveza Saveza muzičara, Šidak je uočio pad pretplatnikâ, kao i neplaćanje oglasnih mjesta u listu. Odlučio je popisati sve tvrtke koje su dužne za oglasni prostor i do dvije godine, zbog čega je list jedva krpao kraj

\footnotetext{
„Fondovi i posredovanje rada u sindikalnoj borbi“, Muzičar (Zagreb), god. VI, br. 8, 28. 8. 1928., 1-2.

8 "Pola decenije Muzičara“, Muzičar (Zagreb), god. VII, br. 3, 15. 3. 1929., 1-2.

69 Isto.

70 Isto.
} 
s krajem. U takvu je raspoloženju i dao ostavku na mjesto urednika. Otišao je s posla koji je obavljao krajnje odgovorno i s ljubavlju, a novu je pronašao u historiografiji. Od 1948. brižno je uređivao Historijski zbornik.

Jaroslav Šidak je u Savezu muzičara i njegovu glasilu Jugoslavenskom muzičaru/Muzičaru radio odgovorno, predano i marljivo. Uz malo novca kojim je raspolagao, davao je izvrsne rezultate. U njegovim se člancima jasno vidi da je duboko ušao u problematiku i materiju glazbenog svijeta te da je svim silama htio promijeniti nepovoljne društvene okolnosti koje su morile glazbenike tog vremena.

No, kako su prolazile godine, tako je jenjavao i Šidakov entuzijazam. Shvatio je da neke stvari ipak ne može promijeniti. Neki su njegovi prijedlozi, poput onih za uvođenje posmrtnog fonda, koncesije salonskih vođa i sl., ugledali svjetlo dana, ali je Šidak smatrao da je to samo kap u moru svega što bi se za muzički stalež moralo i moglo napraviti. Glazbenike je oduvijek smatrao posebnim staležom, što je neprestano isticao, kao i to da je Savez muzičara zasebna staleška organizacija. Šidakovo zalaganje u Muzičaru te ljubav prema glazbi i glazbenicima uistinu su vidljivi u njegovim člancima. Njegova želja bila je da se hrvatska i zagrebačka glazba te glazbeni život dovedu na razinu s drugim europskim gradovima.

$\cos$

\section{JAROSLAV ŠIDAK AND THE ZAGREB MUSIC SCENE}

BETWEEN THE TWO WORLD WARS

Summary: Based on archival materials and an analysis of the publication Jugoslavenski muzičarl Muzičar, this paper looks at the work of Jaroslav Šidak and his involvement with the Zagreb music scene between the two world wars. Jaroslav Šidak served as the editor in chief of the aforementioned publication between 1927 and 1930 . He had contributed to it as a writer as well as an editor throughout his early twenties, finally resigning from the editorial position in the early summer of 1930, attributing his decision to the overwhelming demands of the job. Clearly, publishing and managing such a highly specialized publication failed to generate a livable income, forcing him instead to focus on other projects. Šidak's works from that period, however, reveal a strong sense of justice and the desire to help his peers in achieving their goals, the very traits that the historians who later collaborated with him during his university and particularly his time as the editor-inchief of Historijski zbornik remembered as his defining personality traits.

Key words: Jaroslav Šidak, Fran(jo) Šidak, Jugoslavenski muzičar, The Association of Musicians of the Kingdom of Serbs, Croats and Slovenes, Zagreb, culture 


\section{$\cos$}

\section{Izvori}

Arhiv Jugoslavije (AJ)

AJ-66, fond Ministarstvo prosvete Kraljevine Jugoslavije (Ministarstvo prosvete KJ), Umetničko odelenje, Muzička umetnost/Pevačka i muzička društva, kut. 371.

AJ-66, fond Ministarstvo prosvete Kraljevine Jugoslavije (Ministarstvo prosvete KJ), Umetničko odelenje, Muzička umetnost/Pevačka i muzička društva, kut. 620.

Jugoslavenski muzičar/Muzičar (Zagreb), 1923. - 1924., 1926. - 1931., 1933., 1937., 1940.

\section{Literatura}

Leksikon Jugoslavenske muzike (ur. Krešimir Kovačević), knj. I., Zagreb 1984.

Sanja Majer Boвetкo, Glazbena kritika na hrvatskom jeziku izmecu dvaju svjetskih ratova, Zagreb 1994.

Ивана Весић і Весна Пено, Између уметности и живота. О делатности удружења музичара у Краљевини СХС/Југославији, Beograd 2017. 
